Research Journal of Applied Sciences 13 (9): 491-498, 2018

ISSN: $1815-932 \mathrm{X}$

(C) Medwell Journals, 2018

\title{
Improving the Quality of Recycled Aggregate Concrete to Meet Construction Standards: A Case Study in Euphrates Basin in the Eastern Region of Syria
}

\author{
${ }^{1}$ Moslem J. Shamiah, ${ }^{2}$ Maad S. Madlaji and ${ }^{2}$ Abdullah G. Nassour \\ ${ }^{1}$ Syrian Virtual University, Damascus, Syria \\ ${ }^{2}$ Department of Engineering Management, Faculty of Civil Engineering, \\ University of Aleppo, Aleppo, Syria \\ ${ }^{3}$ Department of Waste Management, Faculty of Agricultural and Environmental Science, \\ University of Rostock, Rostock, Germany
}

\begin{abstract}
This study aims at exploring the way of decreasing effects of impurities (such as clay and dust) of recycled aggregates on concrete quality in the Eastern area, Syria by excluding the detrimental materials retained on the pan. After that, properties of concrete have been investigated to test its conformity to structural requirements. For that, about 30 specimens collected from different mixesof recycled aggregates were casted and tested. Portland cement $(290-510) \mathrm{kg} / \mathrm{m}^{3}$, water/cement ratio $(0.33-0.66)$ and tap water were used. The compressive strength values of concrete cubes varied between 25-5 MPa, noting that strength development was monitored under continuous curing in tap water, up to 91 days. Within 28 days, modulus of elasticity of the specimens varied from 25-40 GPa which refers to good quality concrete. The flexural strength of these concretes was around $6 \mathrm{MPa}$. Also, the workability of concrete batches was good because of using plasticizers. Based on results, the properties of recycled aggregate concreteare able to produce concrete which meets construction standards after discarding the impurities through the pan.
\end{abstract}

Key words: Demolition, impurities, pan, quality, recycled aggregate concrete, strength

\section{INTRODUCTION}

Recycling of concrete agglomerates from damaged buildings as a coarse and fine aggregate in new construction can distribute in supporting infrastructure works (Brandes and Kurama, 2016). This aggregate can be used as a replacement of natural aggregates for a concrete production to reserve the natural resources and also to decrease amounts of demolition waste which has to be landfilled (Novakova and Mikulica, 2016).

Recycling Concrete Aggregate (RCA) can be directly used in a new concrete works. And because the aggregate forms around $65 \%$ of concrete volume, the use of recycled aggregate as a replacement of natural aggregate in the producing of concrete has become a widespread practice (Seo and Lee, 2015). Buildings are demolished due to war, natural disasters, reconstruction, etc. Waste concrete has been managed through its landfilling and recycling. Landfilling has become a major problem, especially in countries where land is scare. Thus, the recycling of waste concrete has main environmental benefit, the conservation of natural sources, since, the recycled aggregate mainly including concrete was continuedfor last two decades in India (Awchat and Kanhe, 2008).
The feasibility of using different groups recycled coarse and fine aggregate in structural concrete was completely evaluated by studying the performance of the recycled aggregates, so, several studies revealed a positive movement of such recycled concrete aggregate. However, a lot of researches have been conducted for improving the quality of recycled aggregate concrete by using different qualities of recycled aggregate and somestudies referred that recycled aggregate concrete is generally lower than that of conventional concrete, mainly due to the quality of material used (Xiao et al., 2006). This problem attributed to a lot of admixtures which take place between impurities and concrete agglomerates, especially, during demolition processes (Bury et al., 2006; Moon and Moon, 2002). So, processing centres of construction and demolition waste, segregate and sort all blemished materials from concrete agglomerates before crushing, grinding and converting it into different size aggregates to use it in the civil projects but this process is generally incomplete as required (Florea and Brouwers, 2013; Koshiro and Ichise, 2014). Here, the problem follows the geographic area and the kind of demolished or constructed structures (Ulsen et al., 2013; Pun et al., 2006). And the problem becomes bigger when materials

Corresponding Author: Moslem J. Shamiah, Syrian Virtual University, Damascus, Syria 
come from disintegrating of structures in case of war and natural disasters such as earthquakes or sand storms (Zega et al., 2010).

In the Eastern region of Syria, structures are exposed to both cases either war or sand storms. So, dust and rain sometimes falling together makes cleaning process useless. This case leads to accumulative layers of mud stuck to concerts that may become an essential constituent of concrete itself (BMPs., 2000; Hendriks and Janssen, 2001).

More problems appear in the old wastes at land fills which have not been processed yet as layers of impurities are bigger which needs more care and awareness regarding to this issue (USEPA., 1973). Impurities which mixed to aggregates affect negatively the engineering properties such as absorption, specific gravity, bulk density and other physical properties and consequently the quality of produced concrete (Brand et al., 2015). Hence, the rate of these materials should be determined to check up the conformity of recycled aggregates to construction standards (Song and Ryou, 2014).

Because of war in Syria, especially in the Eastern region and depleting of natural sources of river aggregates, a lot of debris has to be processed in the same areas. Hereafter, it is necessary to look for applicable procedures to decrease the rate of harmful materials in the recycled aggregates according to tolerance limits (Dryzek, 1997). This study is an attempt to develop the conformity of recycled aggregate concrete to the quality needs for construction uses in the Eastern Region, Syria.

\section{MATERIALS AND METHODS}

The recycled coarse and fine aggregates used in this study were collected from the western area of Euphrates River, exactly near Mayadeen city (Fig. 1). The following tests have been achieved on specimens of recycled aggregates:

\footnotetext{
- Sieve Analysis (SA)

- $\quad$ Sand Equivalent (SE)

- Crushing Strength Value (CSV)

- Water Absorption Value (WAV)

- Specific Gravity Value (SGV)
}

According to ASTM D2419 the methodology of this test is to take limited amount from the sand passed from sieve No. 4" ( $4.75 \mathrm{~mm})$, The specimens were mixed with separation liquids such as calcium chloride and glycerin, the mixture of each type mixed together inside graduated

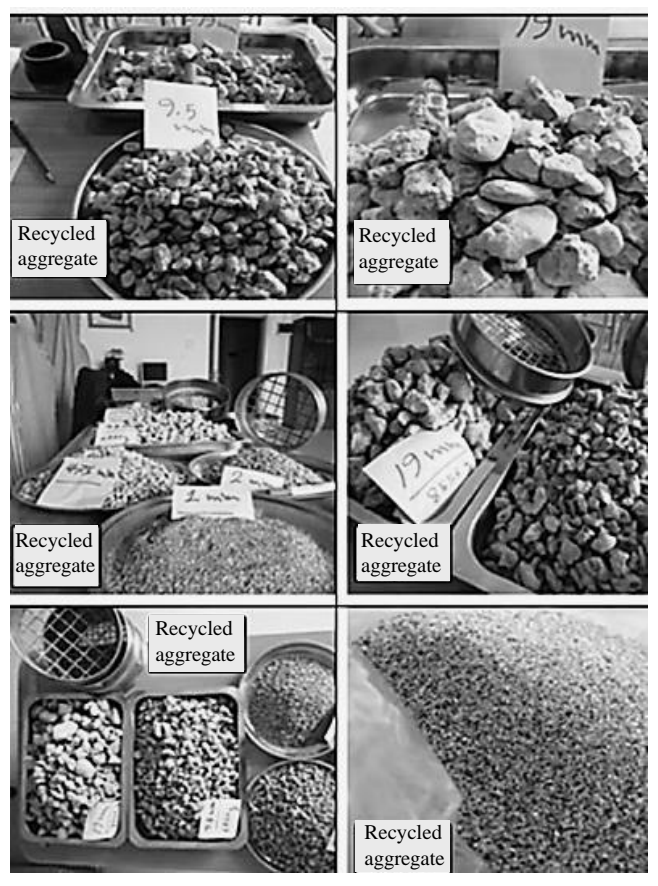

Fig. 1: Part of sieving processes

\begin{tabular}{|c|c|c|c|c|}
\hline $\begin{array}{l}\text { Aggregate } \\
\text { properties }\end{array}$ & $\begin{array}{l}\text { Coarse } \\
(\mathrm{RCA})\end{array}$ & $\begin{array}{l}\text { Fine } \\
(\mathrm{RCA})\end{array}$ & $\begin{array}{l}\text { Natural } \\
\text { coarse }\end{array}$ & $\begin{array}{l}\text { Natural } \\
\text { sand }\end{array}$ \\
\hline SGV & 2.43 & 2.41 & 2.65 & 2.66 \\
\hline CSV-KN & 123 & -- & -- & -- \\
\hline WAV\% & 4.2 & 6.3 & 0 & 0 \\
\hline
\end{tabular}

vertical glassy cylinder manufactured for this test, the mixtures were left in cylinders for $30 \mathrm{~min}$, the sand particles will deposit as a layer in the bottom of each cylinder while other light material layers in the top. After taking the measures of layers in each cylinder and apply calculations according to the following equation:

$$
\mathrm{SE}=\frac{\mathrm{H}_{2}}{\mathrm{H}_{1}} \times 100
$$

Where:

$\mathrm{SE}=$ The Sand Equivalent value

$\mathrm{H}_{1}=$ The Height of soft materials upon the bottom of cylinder (total height of materials)

$\mathrm{H}_{2}=$ The Height of sand in the cylinder

It was clearly that most of soft materials passed through sieve No. 4" $(4.75 \mathrm{~mm})$ and all fine materials retained on the pan were excluded from the whole concrete mixtures of the five samples asmost of harmful materials (clay and dust) retained on the pan Fig. 2 while Table 1 shows the sand equivalent values resulted in this test. 


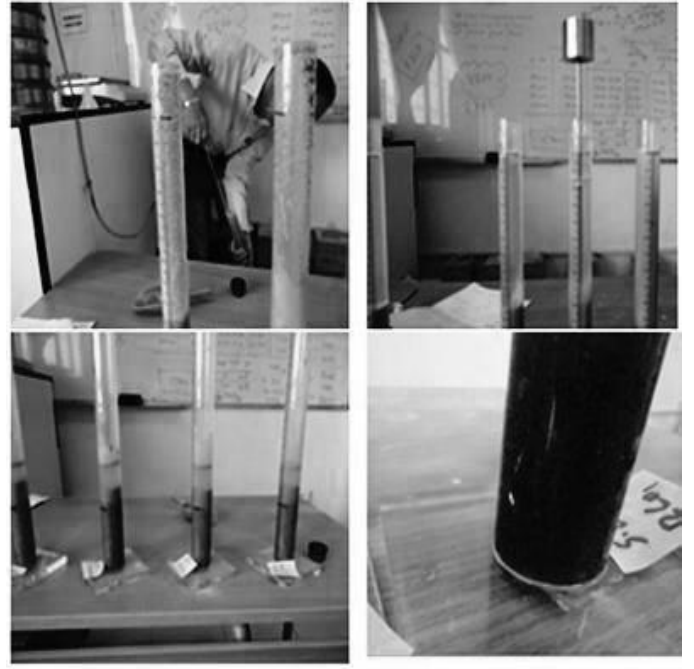

Fig. 2: Part of sand equivalent test

Actually, this practical method can develop the quality of recycled aggregate to meet construction standards. Moreover, it decreases the effects of soft material, especially the dust resulted from sand storms that beating the area continuously.

After that, to make sure the sand (both recycled or natural) become clean by removing the harmful materials from the pan, around 30 concrete batches collected from different mixturesof coarse and fine recycled aggregates (taken from demolition waste in Euphrates Basin area) were casted and tested. Recycled coarse aggregates of maximum diameter size 19 and $12.5 \mathrm{~mm}$ were used. Recycled fine aggregate as well as conventional fine aggregates were used for different mixes. Plasticizer was used in mixes to improve work ability at a lower water-cement ratio. Normal portland cement was used in addition to tap water, a lot of mixtures $25,30,35,40,45$ and $50 \mathrm{MPa}$ nominal compressive strength were designed. Some of batches were made from both recycled aggregate (coarse and fine) while others were made from recycled coarse and natural fine aggregate. Some mixtures were casted by replacing $50 \%$ recycled fine aggregate with natural sand. Two mixtures were casted with natural coarse aggregates, one with natural sand. Mixes are designated by the target strength of 25,30 , etc., signed by $\mathrm{CC}$ or $\mathrm{CN}$. In CC mixtures both coarse and fine aggregates arerecycled (Mixes 1-6). CN mixes are cast with recycled coarse aggregates and natural sand. Mixes where fine aggregate are a 50:50 combination of both natural and recycled sand are designated by $\mathrm{CN} 0.5$, eventually, the mixtures with only natural aggregates are designated by $\mathrm{NN}$ or NC. Quantities were in $\mathrm{kg}$, used to produce a cubic meter of various concretes areincluded in Table 2. All the
Table 2: Sand equivalent values before discarding the harmful materials from the pan

\begin{tabular}{|c|c|c|c|c|c|}
\hline \multicolumn{6}{|c|}{ Sand Equivalent value (SE) } \\
\hline Samples & Natural & RCA1 & RCA2 & RCA3 & RCA4 \\
\hline S.E & 46.41 & 58.83 & 69.18 & 72.12 & 64.48 \\
\hline
\end{tabular}

mixes in Table 3 were cured in water tanks stored in temperature at $15^{\circ} \mathrm{C}$ while air-cured specimens were placed outside the control room on the roof of the laboratory.

The water/cement ratio used in this study varied between $0.33-0.67$ and the slump variedfrom $7-20 \mathrm{~cm}$. It can be seen in Table 3 and 4 that for mixes with $440 \mathrm{~kg} / \mathrm{m}^{3}$ cement even lower water/cement ratios produced more workable mixes (Mixes 7, 9, 10, 11, 13). The concretes made were easy to handle and compact. The use of the super-plasticizer facilitates more workable concretes at low water content. All concretes looseslump with time due to the process of on going hydration. It was observed that most of the mixes lost about $5 \mathrm{~cm}$ slump in the first $35 \mathrm{~min}$ after mixing. This shows that temperature monitoring is important while casting concrete.

Compressive strength values change but losses instrength of up to $10 \%$ are common when RCA is used as the only aggregate with respect to concrete made with only comparable natural aggregates (Dhir, 2009). The reasons for the loss in strength is usually associated with the weaker inter facial change area between aggregate and mortar, due to the aggregate havinga coat of weak mortar already attached (Otsuki et al., 2003; Etxeberria et al., 2006) and this attached mortar raising the porosity of the concrete (Gomez-Soberon, 2002; De Juan and Gutierrez, 2009). The resultant bond between coarse RCA and mortar is not strong as it in virgin aggregates. In order to overcome this problem, most mixes were cast with asuperplasticizer. Concretes of this series with both coarse and fine RCA were made using $295-440 \mathrm{~kg}$ of cement for a cubic meter of concrete. The water-cement ratio used variedbetween 0.3-0.67. Concrete made with cement content $>300 \mathrm{~kg} / \mathrm{m}^{3}$ did not show any change in strength between 28 and 91 days (mix 1 ). This could bedue to the lack of the interface between the cement paste and aggregate. These results suggest that up to $300 \mathrm{~kg} / \mathrm{m}^{3}$, cement hydrated suitably in the first 28 days and there was not anexcess of cement to keep hydrating after 28 day sand, hence, develop extra strength.

The maximum strength achieved by using 100\% recycled aggregates is about $40 \mathrm{MPa}$. In the other hand, the recycled coarse and fine aggregates are able to producing $40 \mathrm{MPa}$ compressive strength concrete. 
Res. J. Applied Sci., 13 (9): 491-498, 2018

Table 3: Mixture quantities of the concrete samples

\begin{tabular}{|c|c|c|c|c|c|c|}
\hline Mixture No. & Specimens designation & Cement $\left(\mathrm{kg} / \mathrm{m}^{3}\right)$ & Water $\left(\mathrm{kg} / \mathrm{m}^{3}\right)$ & $\mathrm{RC}$ coarse $\left(\mathrm{kg} / \mathrm{m}^{3}\right)$ & $\mathrm{RC}$ fine $\left(\mathrm{kg} / \mathrm{m}^{3}\right)$ & Natural sand $\left(\mathrm{kg} / \mathrm{m}^{3}\right)$ \\
\hline 1 & $25 \mathrm{CC}$ & 290 & 190 & 1209 & 623 & - \\
\hline 2 & $30 \mathrm{CC}$ & 310 & 195 & 1046 & 621 & - \\
\hline 3 & $35 \mathrm{CC}$ & 372 & 212 & 1045 & 601 & - \\
\hline 4 & $35 \mathrm{CC}$ & 442 & 225 & 1044 & 533 & - \\
\hline 5 & $40 \mathrm{CC}$ & 440 & 195 & 1047 & 534 & - \\
\hline 6 & $30 \mathrm{CC}$ & 346 & 232 & 1002 & 683 & - \\
\hline 7 & $35 \mathrm{CN}$ & 440 & 137 & 1045 & - & 580 \\
\hline 8 & $40 \mathrm{CN}$ & 372 & 150 & 1046 & - & 655 \\
\hline 9 & $40 \mathrm{CN}$ & 440 & 168 & 1046 & - & 578 \\
\hline 10 & $40 \mathrm{CN}$ & 440 & 165 & 1046 & - & 579 \\
\hline 11 & $45 \mathrm{CN}$ & 440 & 156 & 1046 & - & 577 \\
\hline 12 & $40 \mathrm{CN}$ & 370 & 210 & 1046 & - & 654 \\
\hline 13 & $45 \mathrm{CN}$ & 444 & 145 & 1046 & - & 580 \\
\hline 14 & $50 \mathrm{CN}$ & 472 & 144 & 1046 & - & 579 \\
\hline 15 & $50 \mathrm{CN}$ & 510 & 175 & 1043 & - & 513 \\
\hline 16 & $50 \mathrm{CN}$ & 427 & 148 & 1047 & - & 653 \\
\hline 17 & $50 \mathrm{CN}$ & 425 & 209 & 1045 & - & 653 \\
\hline 18 & $30 \mathrm{CN} 0.5$ & 312 & 138 & 1045 & 310 & 337 \\
\hline 19 & $45 \mathrm{CN} 0.5$ & 371 & 155 & 1045 & 300 & 327 \\
\hline 20 & $45 \mathrm{CN} 0.5$ & 372 & 150 & 1045 & 299 & 326 \\
\hline 21 & $50 \mathrm{CN} 0.5$ & 442 & 165 & 1045 & 266 & 290 \\
\hline 22 & $50 \mathrm{CN} 0.5$ & 440 & 162 & 1045 & 266 & 290 \\
\hline 23 & $30 \mathrm{CC}$ & 346 & 195 & 1001 & 682 & - \\
\hline 24 & $40 \mathrm{CC}$ & 440 & 179 & 1045 & 533 & - \\
\hline 25 & $40 \mathrm{CN}$ & 371 & 134 & 1045 & - & 653 \\
\hline 26 & $50 \mathrm{CN}$ & 427 & 147 & 1045 & - & 579 \\
\hline 27 & $30 \mathrm{CN} 0.5$ & 311 & 169 & 1045 & 310 & 337 \\
\hline 28 & $45 \mathrm{CN} 0.5$ & 371 & 144 & 1045 & 299 & 326 \\
\hline 29 & $50 \mathrm{CN} 0.5$ & 425 & 147 & 1045 & 265 & 290 \\
\hline 30 & $40 \mathrm{NC}$ & 371 & 171 & 1045 & - & - \\
\hline$\underline{31}$ & $50 \mathrm{NN}$ & 440 & 168 & 1210 & 598 & 579 \\
\hline
\end{tabular}

Table 4: Properties of different concrete batches*

Compressive strength (MPa)

\begin{tabular}{|c|c|c|c|c|c|c|c|}
\hline \multirow[b]{2}{*}{ Mixture No. } & \multirow[b]{2}{*}{ Specimens designation } & \multirow[b]{2}{*}{$\mathrm{W} / \mathrm{C}$} & \multirow[b]{2}{*}{ Slump (cm) } & \multirow[b]{2}{*}{ Air content $(\%)$} & \\
\hline & & & & & 7 (days) & 28 (days) & 91 (days) \\
\hline \multicolumn{8}{|l|}{ Group 1} \\
\hline 1 & $25 \mathrm{CC}$ & 0.650 & 10.9 & 2.1 & 22.1 & 27.10 & 29.0 \\
\hline 2 & $30 \mathrm{CC}$ & 0.622 & 14.2 & 2.2 & 25.5 & 32.90 & 39.0 \\
\hline 3 & $35 \mathrm{CC}$ & 0.571 & 9.1 & 1.9 & 28.6 & 35.70 & 40.5 \\
\hline 4 & $35 \mathrm{CC}$ & 0.502 & 20.0 & 2.0 & 32.0 & 35.50 & 40.0 \\
\hline 5 & $40 \mathrm{CC}$ & 0.452 & 19.9 & 2.1 & 33.0 & 40.30 & 46.0 \\
\hline 6 & $30 \mathrm{CC}$ & 0.671 & 12.1 & 2.2 & 23.5 & 32.60 & 33.5 \\
\hline \multicolumn{8}{|l|}{ Group 2} \\
\hline 7 & $35 \mathrm{CN}$ & 0.322 & 9.2 & 2.0 & 36.0 & 36.50 & 50.0 \\
\hline 8 & $40 \mathrm{CN}$ & 0.412 & 14.1 & 1.4 & 35.5 & 42.50 & 37.0 \\
\hline 9 & $40 \mathrm{CN}$ & 0.386 & 10.0 & 1.8 & 26.4 & 39.70 & 45.0 \\
\hline 10 & $40 \mathrm{CN}$ & 0.365 & 12.0 & 1.9 & 42.5 & 44.30 & 46.0 \\
\hline 11 & $45 \mathrm{CN}$ & 0.353 & 16.1 & 1.7 & 40.5 & 45.70 & 49.0 \\
\hline \multicolumn{8}{|l|}{ Group 3} \\
\hline $12^{*}$ & $40 \mathrm{CN}$ & 0.568 & 9.0 & 1.9 & 18.5 & 27.00 & 29.0 \\
\hline 13 & $45 \mathrm{CN}$ & 0.328 & 10.6 & 1.8 & 35.0 & 49.00 & 50.0 \\
\hline 14 & $50 \mathrm{CN}$ & 0.303 & 10.0 & 2.2 & 42.7 & 50.00 & 52.0 \\
\hline 15 & $50 \mathrm{CN}$ & 0.347 & 7.1 & 2.5 & 46.5 & 51.30 & 50.0 \\
\hline 16 & $50 \mathrm{CN}$ & 0.345 & 11.0 & 1.9 & 46.5 & 51.50 & 52.0 \\
\hline $17^{*}$ & $50 \mathrm{CN}$ & 0.491 & 4.5 & 2.0 & 31.0 & 36.55 & 36.8 \\
\hline \multicolumn{8}{|l|}{ Group 4} \\
\hline 18 & $30 \mathrm{CN} 0.5$ & 0.446 & 8.0 & 1.8 & 32.5 & 35.50 & 44.0 \\
\hline 19 & $45 \mathrm{CN} 0.5$ & 0.418 & 8.1 & 2.1 & 31.0 & 47.00 & 52.0 \\
\hline 20 & $45 \mathrm{CN} 0.5$ & 0.405 & 11.1 & 2.5 & 35.5 & 41.00 & 44.0 \\
\hline 21 & $50 \mathrm{CN} 0.5$ & 0.373 & 7.1 & 2.2 & 31.0 & 50.00 & 50.5 \\
\hline 22 & $50 \mathrm{CN} 0.5$ & 0.367 & 7.6 & 2.6 & 45.0 & 51.00 & 51.6 \\
\hline
\end{tabular}

*Concrete patches were casted without adding plasticizer 


\section{RESULTS AND DISCUSSION}

The grain size distribution of the aggregates is shown in Fig. 3 while the physical figures are included in Table 1. Parameters of the first group models (1-6), the second group (7-11), the third group (12-17) and other groups are shown in the Table 3-6. In Table 3, designated as $\mathrm{CC}$, belong to this group.

From Table 1, it was noticed that SEV of natural sand is decreased (46.41) whereas it is increased in RCA1 (58.83), RCA2 (69.18), RCA3 (72.12) and RCA4 (64.48). According to American standards ASTM, SEV of normal strength concrete it should be 75 and more than 80 for the high strength concrete (Sarkis, 2000). After we exclude the pan materials from concrete mixtures, the compression test values met the international standards and specifications, Table 4 shows that compression test values after 28 days varied between 27 and $53 \mathrm{MPa}$. When recycled fine aggregate was replaced by natural sand, the purpose is to develop compressive strength of the concrete. For example, mixes 3 and 8 are comparable in terms of total cement content of $372 \mathrm{~kg} / \mathrm{m}^{3}$ of concrete. The replacement of recycled sand by natural sand achieved to lower the $\mathrm{w} / \mathrm{c}$ ratio and hence, develop the strength for the same slump. Again, there does not seem to be an considerable development in strength of this groups of concrete between 28 and 91 days. The longterm strength seems to be limited by the amount of cement and the strength capacity of there cycled coarse aggregates as well. Using a higher cement content of $440 \mathrm{~kg} / \mathrm{m}^{3}$, a maximum strength of $49 \mathrm{MPa}$ was achievable (mix 11). The use of both 19 and $12.5 \mathrm{~mm}$ of aggregates in same weight with natural sand has further developed the strength potential of these concretes compared tothose using $19 \mathrm{~mm}$ aggregates only. This is attributed to more desirable packing of the resultant aggregate solid structure (compare mixes 10 and 13). However, there is no remarkable change in strength between 28 and 91 days (only $3 \%$ increase) even with a considerable higher amount of total cement (mixture 15 with $510 \mathrm{~kg} / \mathrm{m}^{3}$ of cement).

This indicates the use of coarse recycled concrete aggregate incombination with natural sand tested in this study can produce concrete of no more than $50 \mathrm{MPa}$ compressive strength. Two mixes in this series were cast without plasticizer (mixes 12 and 17).

Similar mixes cast with plasticizer (mix 12 with 8 and mix 17 with 16) clearly indicates that, the $\mathrm{w} / \mathrm{c}$ ratio had to be increased to sustain work ability, which decreased the strength considerably ( $38.8 \%$ reduction for mix 12 and $28.8 \%$ reduction for mix 17 in 28 days strength). This indicates that the use of super-plasticizer in the recycled aggregate concrete will play a dynamic character.

Concretes made with $19 \mathrm{~mm}$ recycled aggregates and $50 \%$ natural sand and 50\% recycled fine aggregate have considerably enhanced strength than concretesmade with $100 \%$ recycled (compare mix 3 with 19 and mixes 4,5 with 22). Concretes made with 50:50 are as good as those with $100 \%$ natural sand. Except mixes 19 and 21 all other mixes were cast with coarse aggregate of 19 and $12.5 \mathrm{~mm}$ size in

Table 5: Compressive strength development of concretes

\begin{tabular}{|c|c|c|c|c|c|c|c|c|c|}
\hline \multirow{3}{*}{ Mixture No. } & \multirow{3}{*}{ Specimens designation } & \multirow{3}{*}{$\mathrm{W} / \mathrm{C}$} & \multirow{3}{*}{ Cement $\left(\mathrm{kg} / \mathrm{m}^{3}\right)$} & \multirow{3}{*}{ Slump (cm) } & \multirow{3}{*}{ Air content $(\%)$} & \multicolumn{4}{|c|}{ Cube strength (MPa) } \\
\hline & & & & & & \multicolumn{2}{|c|}{ Normal curing (days) } & \multicolumn{2}{|c|}{ Without curing (days) } \\
\hline & & & & & & 28.0 & 91 & 28.0 & 91.0 \\
\hline 5 & $40 \mathrm{CC}$ & 0.4150 & 440 & 17.9 & 1.6 & 39.0 & 45 & 49.0 & 44.5 \\
\hline 6 & $30 \mathrm{CC}$ & 0.5510 & 346 & 7.9 & 3.2 & 32.0 & 34 & 28.0 & 29.5 \\
\hline 8 & $40 \mathrm{CN}$ & 0.3480 & 372 & 10.3 & 2.7 & 42.5 & 36 & 23.5 & 35.5 \\
\hline 16 & $50 \mathrm{CN}$ & 0.3450 & 425 & 17.7 & 1.5 & 51.5 & 51 & 36.5 & 41.5 \\
\hline 18 & $30 \mathrm{CN} 0.5$ & 0.5412 & 311 & 14.1 & 2.5 & 32.0 & 34 & 28.5 & 27.5 \\
\hline 19 & $45 \mathrm{CN} 0.5$ & 0.3760 & 371 & 9.2 & 2.6 & 47.0 & 52 & 45.5 & 40.5 \\
\hline 21 & $50 \mathrm{CN} 0.5$ & 0.3470 & 424 & 10.5 & 2.1 & 51.5 & 51 & 53.5 & 46.5 \\
\hline 30 & $40 \mathrm{NC}$ & 0.4620 & 372 & 11.1 & 1.7 & 49.0 & 51 & 33.0 & 39.5 \\
\hline 31 & $50 \mathrm{NN}$ & 0.3800 & 440 & 7.3 & 2.1 & 48.0 & 51 & 43.0 & 55.5 \\
\hline
\end{tabular}

Table 6: Flexural strength and E values of samples

\begin{tabular}{|c|c|c|c|c|c|c|c|}
\hline Mix No. & $\begin{array}{l}\text { Specimens } \\
\text { designation }\end{array}$ & $\begin{array}{l}28 \text { days flexural } \\
\text { strength }(\mathrm{MPa})\end{array}$ & $\begin{array}{l}\text { Density } \\
\left(\mathrm{kg} / \mathrm{m}^{3}\right)\end{array}$ & $\begin{array}{l}28 \text { days comp. } \\
\text { strength (MPa) }\end{array}$ & $\begin{array}{l}\text { Experimental } \\
(\mathrm{GPa})\end{array}$ & $\begin{array}{c}\text { Valuesas/AS3600 } \\
\text { (GPa) }\end{array}$ & $\begin{array}{c}\text { Values as/ } \\
\mathrm{ACI} 318(\mathrm{GPa}) \\
\end{array}$ \\
\hline 1 & $50 \mathrm{CN}$ & 5.6 & 2343 & 53.5 & 35.8 & 35.6 & 34.6 \\
\hline 2 & $40 \mathrm{CN}$ & 5.4 & 2332 & 33.0 & 33.6 & 27.5 & 26.9 \\
\hline 3 & $30 \mathrm{CC}$ & 5.2 & 2227 & 32.5 & 29.2 & 25.4 & 26.8 \\
\hline 4 & $45 \mathrm{CN} 0.5$ & 5.5 & 2310 & 47.4 & 34.8 & 32.8 & 32.1 \\
\hline 5 & $40 \mathrm{CC}$ & 5.1 & 2322 & 41.2 & 25.0 & 30.7 & 30.6 \\
\hline 6 & $50 \mathrm{CN} 0.5$ & 4.7 & 2359 & 44.5 & 26.1 & 32.7 & 31.3 \\
\hline 7 & $30 \mathrm{CN} 0.5$ & 3.7 & 2275 & 28.0 & 27.8 & 24.9 & 25.2 \\
\hline 8 & $50 \mathrm{NN}$ & 5.3 & 2526 & 51.5 & 39.4 & 39.2 & 33.2 \\
\hline 9 & $50 \mathrm{NC}$ & 6.2 & 2460 & 43.6 & 33.4 & 34.2 & 31.8 \\
\hline
\end{tabular}




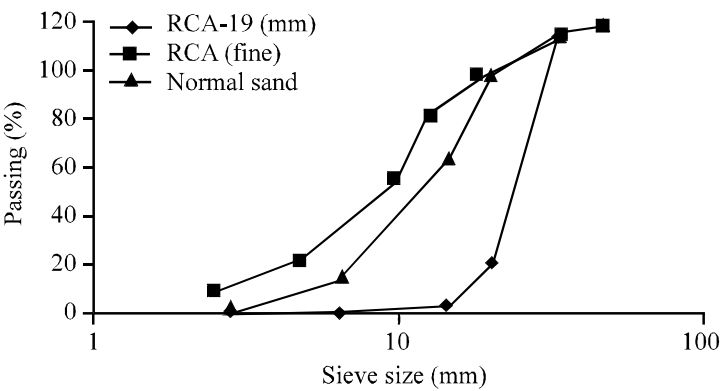

Fig. 3: Grain size distribution of aggregates used

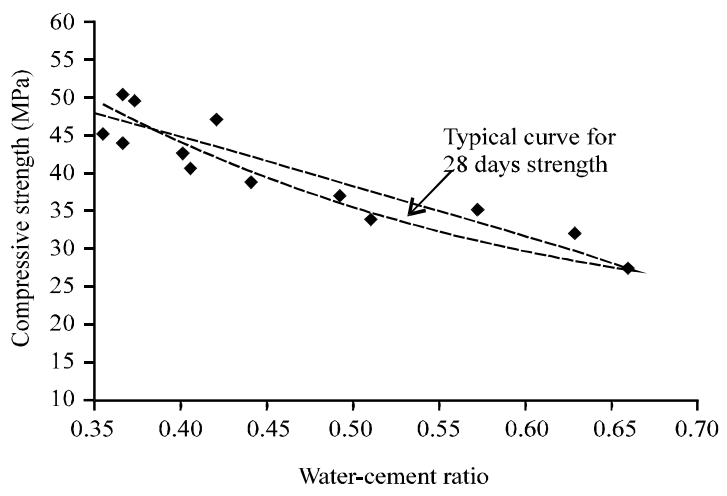

Fig. 4: Variation of compressive strength for RCA concrete with $\mathrm{w} / \mathrm{c}$ ratio

equal proportion. This further improved the compressive strength development. Again, the maximum compressive strength achievable using these recycled concrete aggregates appears to be around $50 \mathrm{MPa}$. The results show thatusing normal practices, the recycled concrete aggregates from the present source canproduce $50 \mathrm{MPa}$ concrete. Figure 4 shows a plot of water-cement ratio versus compressive strength (28 days) of the concretes produced. The data is close to the distinctive 28 days strengthcurve (Mehta and Monteiro, 2006) based on Abram's cone rule.

A straightline best fit is drawn through the plotted points for comparison. This suggests that Abram's water-cement ratio is applicable to the concretes produced using recycled concrete aggregates.

Modulus values have been determined both experimentally and calculated from the results of strength and density. Cylinders of $150 \times 300 \mathrm{~mm}$ size were used to determine the $\mathrm{E}$ values. Modulus of elasticity was calculated according to Australian Standard AS $3600-2009$, while the modulus of elasticity was also calculated using ACI 318. The cylinders were tested for modulus of elasticity according to ASTM C469-02 at 28 days, after curing in tap water. The values of $E$

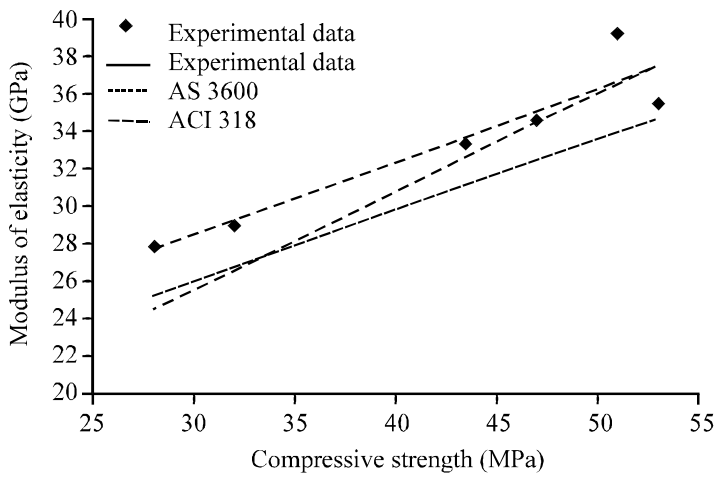

Fig. 5: Modulus of elasticity against compressive strength relationship for RCA concrete

obtained and calculated are listed in Table 6. The experimentally determined values of $\mathrm{E}$ for all the recycled concretes varied approximately between 24-39 GPa. These results suppose that these concretes are satisfactorilyfirm and further these values are similar to those of virgin aggregate concretes. The variation of $\mathrm{E}$ with the concrete compressive strength are similar to those of the virgin aggregate concrete (Neville,1995). Figure 5 shows the variation of $\mathrm{E}$ with compressive strength. Plots of E-values calculated as per AS 3600 and AC 1318 equations are also included in Fig. 5. The experimental E-values are slightly higher than those of ACI 318 equation but follow a similar pattern. However, the E-values determined are very close to the E-values calculated by AS 3600 equation as six out of nine specimens showed a good correlation of 0.97 .

Concrete beams of size $100 \times 100 \times 500 \mathrm{~mm}$ were cast and tested for flexural strength according to ASTM C 7802 after 28 days of tap water curing. As indicated in Table 6 , the results show that RCA gave equal performance to that of natural aggregate concrete (compare flexural strength of $50 \mathrm{CN}, 50 \mathrm{NN}$ and $50 \mathrm{NC}$ mixes).

Figure 6 shows the plot between flexural strength and compressive strength ofsome samples tested in this study. The relationship shown is very similarto that between the flexural strength and the compressive strength of concretesmade with virgin aggregates (Neville, 1995). For the concretes plotted in Fig. 6, the flexural strength is about $12 \%$ of the compressive strength which again is similar tothat reported for natural aggregate concretes (Neville, 1995). Further, the variation off lexural strength showed a reasonably good correlation of 0.78 with the compressive strength for the plotted specimens. However, this correlation is only an approximation, because the relationship between flexural and compressive strengths is affected by the mix components and their proportions. 


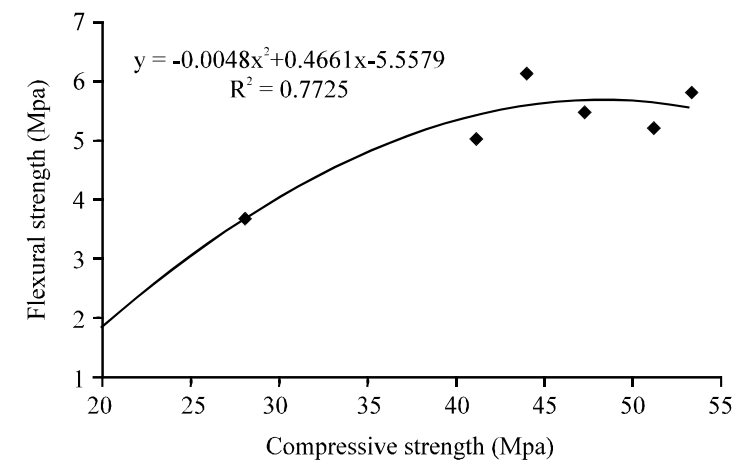

Fig. 6: Variation of flexural strength with compressive strength for RCA concrete

Commonly, the properties of recycled aggregate concrete have been established and demonstrated through several experimental and field projects. It has been concluded that RCA can be easily used in construction of low rise buildings, concrete paving blocks and tiles, flooring, retaining walls, approaching lanes, sewerage structures, subbase course of pavement, drainage layer in highways and dry lean concrete, etc. Recycling and reuse of construction and demolition waste is the appropriate solution tothe environmental problems caused due to the dumping of enormous quantity of debrisand the substantial depletion of natural resources.

Eventually, there was not remarkable change in compressive strength between 28 and 91 days even with a considerable higher amount of total cement (mix 18 with $510 \mathrm{~kg} / \mathrm{m}^{3}$ of cement). This indicates that the continued curing after 28 days declines the porous mortar attached to aggregates and thus, prevent further enhancement of strength. In such case, the RCA can meet the quality requirements for construction in the East of Syria.

\section{CONCLUSION}

Simply, It can be said that most of harmful soft materials can easily be separated from concrete agglomerates and grinded in different recycling processes, then they passed through sieve $(75 \mu)$ and retained in the pan. So, experimental results have proved that soft materials (clay and dust) in recycled and natural aggregates in Euphrates River basin can be detached from aggregate mixtures through the pan, this could be a practical procedure in processing centres. After this method astructural concretes of 27-50 $\mathrm{MPa}$ cube compressive strength can be produced using the recycled coarse $(100 \%)$ and fine aggregate produced locally in East of Syria.
Other physical properties like bulk density, surface texture, particle size distribution and absorption are suited to some concrete production. The compressive strength values in the range of $35-50 \mathrm{MPa}$, the modulus of elasticity values 24-39 GPa and flexural strength 3.7-6.2 MPa suggest that recycled aggregate concrete produced can be used in structural applications.

\section{ACKNOWLEDGEMENTS}

The researchers would like to thank Aljazeera Private University management in Syria as they provided the laboratory equipment and tools also the doctoral program director in the Syrian Virtual University and Department of Waste Management, Faculty of Agricultural and Environmental Science, University of Rostock, Germany for their appreciated efforts to make this research successful.

\section{REFERENCES}

Awchat, G.D. and N.M. Kanhe, 2008. Some Studies on Recycled Aggregate Concrete with and without Polymer. In: Geotechnical Engineering for Disaster Mitigation and Rehabilitation, Liu, H., A. Deng and J. Chu (Eds.). Springer, Berlin, Germany, ISBN:978-3-540-79845-3, pp: 1019-1025.

BMPs., 2000. Stormwater Quality Handbooks Construction Site. Best Management Practices (BMPs), California Department of Transportation, Sacramento, California, US..

Brand, A.S., J.R. Roesler and A. Salas, 2015. Initial moisture and mixing effects on higher quality recycled coarse aggregate concrete. Constr. Build. Mater., 79: 83-89.

Brandes, M.R. and Y.C. Kurama, 2016. Use of recycled concrete aggregates in precast-prestressed concrete. Procedia Eng., 145: 1338-1345.

Bury, M.A., C.A. Mawby and D. Fisher, 2006. Making pervious concrete placement easy using a novel admixture system. Concr. Focus, 5: 55-59.

De Juan, M.S. and P.A. Gutierrez, 2009. Study on the influence of attached mortar content on the properties of recycled concrete aggregate. Constr. Build. Mater., 23: 872-877.

Dhir, R.K., 2009. Towards value added sustainable use of recycled and secondary aggregates in concrete: Fundamentals, knowledge, impact and practice. Building and Construction Authority, Singapore.

Dryzek, J.S., 1997. The Politics of the Earth: Environmental Discourses. Oxford University Press, Oxford, England, UK., ISBN:9780198781592, Pages: 220. 
Etxeberria, M., E. Vazquez and A. Mari, 2006. Microstructure analysis of hardened recycled aggregate concrete. Mag. Concr. Res., 58: 683-690.

Florea, M.V.A. and H.J.H. Brouwers, 2013. Properties of various size fractions of crushed concrete related to process conditions and re-use. Cem. Concr. Res., 52: 11-21.

Gomez-Soberon, J.M., 2002. Porosity of recycled concrete with substitution of recycled concrete aggregate: An experimental study. Cem. Concr. Res., 32: 1301-1311.

Hendriks, C.F. and G.M.T. Janssen, 2001. Construction and demolition waste: General process aspects. Heron, 46: 79-87.

Koshiro, Y. and K. Ichise, 2014. Application of entire concrete waste reuse model to produce recycled aggregate class H. Constr. Build. Mater., 67: 308-314.

Mehta, P.K. and P.J.M. Monteiro, 2006. Concrete, Microstructure, Properties and Materials. 3rd Edn., McGraw-Hill, USA.

Moon, D.J. and H.Y. Moon, 2002. Effect of pore size distribution on the qualities of recycled aggregate concrete. KSCE. J. Civil Eng., 6: 289-295.

Neville, A.M., 1995. Properties of Concrete. 4th Edn., Longman, ?Harlow, England, UK.,.

Novakova, I. and K. Mikulica, 2016. Properties of concrete with partial replacement of natural aggregate by recycled concrete aggregates from precast production. Procedia Eng., 151: 360-367.
Otsuki, N., S.I. Miyazato and W. Yodsudjai, 2003. Influence of recycled aggregate on interfacial transition zone, strength, chloride penetration and carbonation of concrete. J. Mater. Civil Eng., 15: 443-451.

Pun, S.K., C. Liu, C. Langston, G. Treloar and Y. Itoh, 2006. Promoting the reuse and recycling of building demolition materials. World Trans. Eng. Technol. Educ., 5: 195-200.

Sarkis, F.M., 2000. Material properties. J. Mater. Trans., 1: 233-237.

Seo, T.S. and M.S. Lee, 2015. Experimental study on tensile creep of coarse recycled aggregate concrete. Intl. J. Concr. Struct. Mater., 9: 337-343.

Song, I.H. and J.S. Ryou, 2014. Hybrid techniques for quality improvement of recycled fine aggregate. Constr. Build. Mater., 72: 56-64.

USEPA., 1973. Processes, Procedures and Methods to Control Pollution Resulting from All Construction Activity. United States Environmental Protection Agency, Washington, D.C., USA., Pages: 234.

Ulsen, C., H. Kahn, G. Hawlitschek, E.A. Masini and S.C. Angulo et al., 2013. Production of recycled sand from construction and demolition waste. Constr. Build. Mater., 40: 1168-1173.

Xiao, J.Z., J.B. Li and C. Zhang, 2006. On relationships between the mechanical properties of recycled aggregate concrete: An overview. Mater. Struct., 39: 655-664.

Zega, C.J., Y.A. Villagran-Zaccardi and A.A. Di Maio, 2010. Effect of natural coarse aggregate type on the physical and mechanical properties of recycled coarse aggregate. Mater. Structures, 43: 195-202. 